\title{
The Efficacy of Goutweed (Aegopodium Podagraria L.) Tincture and Metformin Combination in the Early Stages of Alloxan- Induced Diabetes in Rats
}

\author{
O.V. Tovchiga", S.Yu. Shtrygol, Yu. B. Laryanovskaya \\ Department of Pharmacology, the Central Scientific Research Laboratory, National University of Pharmacy, \\ Kharkiv, Ukraine
}

*Corresponding Author: O.V. Tovchiga, Department of Pharmacology, the Central Scientific Research Laboratory, National University of Pharmacy, Kharkiv,Ukraine, Email: farmacol@nuph.edu.ua

\begin{abstract}
The effects of goutweed (Aegopodium podagraria L.) tincture (1 $\mathrm{ml} / \mathrm{kg}$ intragastrically), metformin $(100 \mathrm{mg} / \mathrm{kg}$ intraperitoneally) or their combination were studied in alloxan-induced diabetic rats. On the 4th day after alloxan injection, $\beta$-cells underwent destructive changes and death, the number of pancreatic islets was reduced, proliferation processes were intensified in the places of typical $\alpha$-cells localization. The studied combination normalized the state of the islets counteracting cell death and limiting excessive proliferation foci (evidently $\alpha$-cells), the last effect was not observed after monotherapy in both cases. The tincture and metformin normalized the histological structure of the liver counteracting hepatocytes death, which was intensified in diabetic rats. The protective effect of metformin on the structure of the vascular wall both in the pancreas and the liver was maintained after combined use of this drug with the tincture. This combination also partially restored insulinemia and insulin resistance index, while the effect on glycemia and TNF- $\alpha$ level in plasma was not manifested within the term of the study and under conditions of anaesthesia. The correlation between TNF- $\alpha$ and insulinemia indicates the possible participation of the mechanisms related to this cytokine in the tincture protective effect in regard to $\beta$-cells. Combined use of goutweed tincture with metformin allowed increasing plasma albumin level, which was not observed after monotherapy with metformin.
\end{abstract}

Abbreviations: ALT - alanine aminotransferase, AST-aspartate aminotransferase, $G W$ - goutweed, TNF- $\alpha$ - tumour necrosis factor $\alpha$.

Keywords: Alloxan-Induced Diabetes, Antidiabetic Agents, Goutweed (Aegopodium podagraria L.), Combined Drugs

\section{INTRODUCTION}

Nowadays, substances of herbal origin are under the intensive research as the potential antidiabetic drugs possessing polymodal protective action [1]. The patients are also becoming more interested in traditional herbal medicines and frequently use them as complementary agents, together with conventional drugs, often without medical advice ${ }^{[2]}$. In such situation, herb-drug pharmacokinetic and pharmacodynamic interactions may arise, especially in the case of the crude herbal drugs containing multiple compounds ${ }^{[3]}$. These aspects substantiate a need in the verification of the efficacy and safety of herbal drugs combinations with anti diabetic medicines.

The object of our study is goutweed (Aegopodium podagraria L., GW). It is a perenniall plant of the Apiaceae family indigenous to Europe, Siberia, the Caucasus, Kazakhstan and Central Asia mountainous regions and has been naturalized in North America and Australia. GW is widely used in traditional medicine and consumed as vegetable and as fodder plant ${ }^{[4]}$.

Hydroxycinnamic acids and flavonoids are believed to mediate biological activity of goutweed aerial part to a great extent ${ }^{[5]}$ and just these substances are capable of influence on the key mechanisms of diabetes and metabolic syndrome development ${ }^{[1]}$. Besides, coumarins, polyacetylene compounds, essential oil components, micro- and macroelements, vitamins were identified in $\mathrm{GW}$ aerial part. The capillary electrophoresis method was applied to establishing electrophoretic fingerprints of leaves and stems of Aegopodium podagraria L. 
[6]. The procedures of hydroxycinnamic acids quantitative assay in $\mathrm{GW}$ were described ${ }^{[5,7]}$, and various chromatographic methods were proposed for the analysis of this raw material and the preparations obtained from it ${ }^{[6,7]}$.

The technology of the tincture obtaining from GW aerial part in accordance with the requirements of the State Pharmacopoeia of Ukraine was described previously ${ }^{[8]}$.

Favourable metabolic effects of GW tincture including antidiabetic activity were reported before. In the screening tests this herbal drug demonstrated hypoglycemic action ${ }^{[8]}$. It normalized glycemia level in rats with the metabolic disorders induced by excess fructose combined with hydrochlorothiazide ${ }^{[9]}$ as well as low dose of dexamethasone ${ }^{[10]}$. On the model of severe metabolic impairment caused by high dose of dexamethasone, the effect of GW was moderate, but combining this drug with metformin allowed normalizing basal glycemia as well as peripheral insulin sensitivity and, partially, the results of the oral glucose tolerance test ${ }^{[11]}$. On the model with the primary disorders of the lipid metabolism in rats (administration of protamine sulfate against the background of atherogenic diet) the tincture also showed an ability to increase metformin efficacy in the glucose tolerance test ${ }^{[12]}$. The safety of combined use of Aegopodium podagraria $L$. tincture with metformin was also verified in the intact rat. Besides, in the glucose tolerance test, the tincture at a dose of $1.0 \mathrm{ml} / \mathrm{kg}$ coadministered with metformin allowed decreasing its effective dose ${ }^{[13]}$. The additional benefits of GW tincture are an ability to normalize uric acid metabolism as well as hepatoprotective properties and favourable renal effects ${ }^{[5,12]}$.

Alloxan-induced diabetes remains to be one of the basic models in pre-clinical studies of potential antidiabetic drugs [14-16]. Antihyperglycemic effect of GW tincture after a prolonged administration has been confirmed on this model on mice ${ }^{[17]}$, its influence on the histological structure of the liver and kidney was evaluated ${ }^{[18]}$, but there is no data concerning effects of the tincture combined with metformin. The influence of the combination on the histological structure of the pancreas as well as the liver was not studied and there is no information about its safety and efficacy in the early stages of the pancreas injury. At the same time, antidiabetic activity of metformin on the alloxan-induced model is supported with the strong evidence ${ }^{[19-23]}$.

Thus, the objective of this study is to determine the influence of Aegopodium podagraria $\mathrm{L}$. tincture and its combination with metformin on the on the pancreas and liver structure as well as the metabolic processes in the early stages of the alloxan-induced diabetes in rats.

\section{Materials AND MethodS}

\subsection{Venue}

The whole experimental work was conducted at the Central Scientific-Research Laboratory of National University of Pharmacy, Kharkiv, Ukraine.

\subsection{Plant Material}

The aerial parts of Aegopodium podagraria L. were collected from natural population in Kharkiv region (Ukraine) in June. Voucher specimens of the species were identified by Ass. Prof. Dr. S.I. Stepanova. The herbal raw material was dried at room temperature and powdered using a standard grinding mill. Then the powder was used for the obtaining of the tincture by double extraction with $70 \%$ ethyl alcohol. The technology is standard and corresponds to the requirements of State Pharmacopoeia of Ukraine, and was previously described. Goutweed tincture is dark green liquid with a characteristic odour ${ }^{[8,11]}$.

\subsection{Experimental Animals Used}

Adult randombred male rats (body weight 150 190 grams) obtained from the Central ScientificResearch Laboratory of National University of Pharmacy were used in the study in accordance with "Directive 2010/63/EU of the European Parliament and of the Council of 22 September 2010 on the protection of animals used for scientific purposes".

The rats were housed in a well-ventilated animal room at a controlled temperature and relative humidity, under a natural light-dark cycle. Food and water were supplied ad libitum.

\subsection{Experimental Design and Model}

The animals were randomly divided into 5 groups, as follows:

Group I: intact control (saline solution subcutaneously + tap water intragastrically, $\mathrm{n}=8$ );

Group II: alloxan-induced diabetes + tap water intragastrically (untreated control, $n=14$ ); 
Group III: alloxan-induced diabetes + metformin, $100 \mathrm{mg} / \mathrm{kg}$ intraperitoneally $(\mathrm{n}=8)$;

Group IV: alloxan-induced diabetes + Aegopodium podagraria $L$. tincture, $1 \mathrm{ml} / \mathrm{kg}$ intragastrically $(\mathrm{n}=9)$;

Group V: alloxan-induced diabetes + metformin, $100 \mathrm{mg} / \mathrm{kg}$ intraperitoneally + Aegopodium podagraria $L$. tincture, $1 \mathrm{ml} / \mathrm{kg}$ intragastrically $(\mathrm{n}=8)$.

The model of diabetes presupposed single subcutaneous administration of alloxan monohydrate (Sigma, USA) administration at a dose of $150 \mathrm{mg} / \mathrm{kg}{ }^{[16]}$, that appeared to be effective under the conditions of our laboratory [23] (taking into account the well-known difficulties in the diabetogenic dose adjustment ${ }^{[14]}$ ).

The animals previously were deprived of food for $16 \mathrm{~h}$, but had free access to water. On the first day after the injection 5\% glucose solution was available to the animals to prevent severe hypoglycemia during the acute phase of islets injury with insulin release.

GW tincture was administered intragastrically at daily dose of $1 \mathrm{ml} / \mathrm{kg}$, metformin intraperitoneally at daily dose of $100 \mathrm{mg} / \mathrm{kg}$. The first dose of the tincture was given $40-$ $50 \mathrm{~min}$ before alloxan injection, the first dose of metformin - 40-50 min after it (in attempt to minimize the pharmacokinetic interactions). Afterwards the drugs were administered each day. The animals of the intact control and the untreated control groups received tap water by the similar scheme. On day 4 of the experiment, 40-50 min after the drugs administration, heparinized blood samples were drawn by exsanguination from barbiturate-anesthetized animals, the liver and the pancreas samples were taken. $72 \mathrm{~h}$ is the generally accepted term of the maximum damage of the pancreas by alloxane, at which diabetes is manifested in the most of the rats ${ }^{[15,20]}$, and the histological studies ${ }^{[24]}$ that verified the changes in the pancreas with $24 \mathrm{~h}$ intervals confirm the maximum $\beta$-cell destruction just in this period.

\subsection{Biochemical Methods Used}

Plasma (the anticoagulant heparin in vitro) was separated immediately by centrifugation. Glucose concentration in plasma was measured using the glucose oxidase method. Insulin and TNF- $\alpha$ levels were determined through standard procedure with the ELISA kits (produced by DRG, Germany and Vector Best, Russian Federation, respectively).
Insulin resistance index was calculated by using the following formula:

Index $=($ Glycemia $(\mathrm{mM} / \mathrm{l}) \times$ Insulin level $(\mathrm{mcIU} / \mathrm{ml}) /(\text { Glycemia }(\mathrm{mM} / \mathrm{l})-3,5)^{[15]}$.

The generally accepted routine biochemical methods were applied for blood plasma analysis: total protein concentration was measured by biuret method, albumin level - by the bromcresol green procedure, alanine aminotransferase (ALT) and aspartate aminotransferase (AST) activity were determined according to the method of Reitman and Frankel and De Ritis ratio was calculated. Commercially-available kits from FilisitDiagnostika (Ukraine) were used for these assays as well as for glucose measurement. Liver glycogen content was assayed by the reaction with anthrone reagent.

\subsection{Histological Methods Used}

Fragments of the liver and the pancreas were fixed in $10 \%$ formalin solution, dehydrated in increasing concentrations of ethanol, and embedded in paraffin. The sections were stained with hematoxylin and eosin. The microscope "Granum" and the digital video camera "Granum DCM 310" ("NVL Granum" Ltd, Ukraine) were used, and the photographs were processed using computer Pentium $2,4 \mathrm{GHz}$ through a Toup View program. In the pancreas sections the spatial arrangement of the cells was analyzed.

\subsection{Statistical Evaluation}

Medians, $25 \%$ and $75 \%$ percentiles (upper and lower quartiles) were calculated as recommended for biomedical research. The traditionally used arithmetic means and their standard errors $(\mathrm{M} \pm \mathrm{m})$ are also given. The comparison of the central tendencies of independent samples was performed by the criterion of Mann-Whitney $U$ (taking into account a problematical character of multiple comparisons in pharmacology and toxicology $\left.{ }^{[25]}\right)$. To determine the relationship between the individual parameters, the Spearman's correlation coefficient of $\rho$ was used.

\section{RESULTS AND DISCUSSION}

Alloxan-induced diabetes is a widely used and well studied model of the experimental diabetes mellitus. Being chemically related with glucose, alloxan is transported into the $\beta$-cells by GLUT 2 and accumulated within the pancreas. It is generally accepted that the primary action of alloxan in $\beta$-cells is directed to the mitochondria 
which undergo swelling and disruption of both membranes, consequently resulting in apoptosis. Cell injury is also mediated by DNA fragmentation and NAD depletion. The disturbances of GLUT2 functioning with the decrease in its mRNA expression arise as well as the inhibition of glucokinase with the suppression of glucose-induced insulin secretion. Generation of free radicals (against the background of the poor defence mechanisms of $\beta$-cells to the oxidative injury) together with the elevation of cytosolic free calcium level also contribute to alloxan toxicity ${ }^{[14]}$.

The results of the histological study were in good agreement with these data. In the pancreatic sections of the intact rats there was a normal acinar lobular arrangement with the clear differentiation on the external secretion parenchyma and incretory apparatus which predominated. Acinar structures formed by a single layer of glandular cells were closely adjacent to each other. Basal basophilic zone with the rounded, dense nuclei and an eosinophilic central zone with fine zymogen grains were seen. The ratio of zones was within the range of 1:1.5 - 1:2.5. Intercellular connective tissue was scarce, and there were no noticeable changes in the interstitial excretory ducts, arteries and veins. Epithelial cells in the islets are arranged in strands, which are subdivided by capillaries (sinusoidal capillaries were common and vascular plethora was seen in some islets). The typical for rats arrangement of the cells in the islets ${ }^{[26,27]}$ with the densely filled core $(80-90 \%$ of the total number of islet cells, presumably $\beta$-cells) and peripherally located cells, that may be classified as $\alpha$-cells, was clearly seen.

3 days after alloxan administration, in the pancreatic sections of the untreated rats there was a distortion of the acinar lobular arrangement with the significantly reduced number of pancreatic islets. In a few existing islets, swelling of the stroma, marked cells disjoining (especially in central areas), degenerative changes, signs of karyolysis and cytolysis were detected. In the large part of the cells located within the core of the islets the highly acidophilic cytoplasm as well as condensation and fragmentation of nuclei indicated apoptotic death (Fig. 1a) that is consistent with the data about alloxan mechanism of action on the $\beta$-cells ${ }^{[14]}$ discussed above. Besides, there were signs of $\alpha$-cells apoptosis, such as expressive acidophilia of the condensed cytoplasm and the presence of different size fragments of nuclear material. The massive cell death resulted in the islet desolation (Fig. 1b). Along with these, foci of cells proliferation (evidently $\alpha$-cells or $\Delta$-cells) ${ }^{[28]}$ arose both in the places of typical $\alpha$-cells localization, and unsystematically throughout the islet. It should be mentioned that $\alpha$-cells prevalence in the pancreatic islets was clearly seen in the study ${ }^{[24]}$ within the term and on the model used in our experiments, and it was supposed that the increase in the relative quantity of $\alpha$-cells and, subsequently, glucagon synthesis is the important mechanism of alloxan-induced diabetes development (which, thereby is not limited to the $\beta$-cells damage and dysfunction).

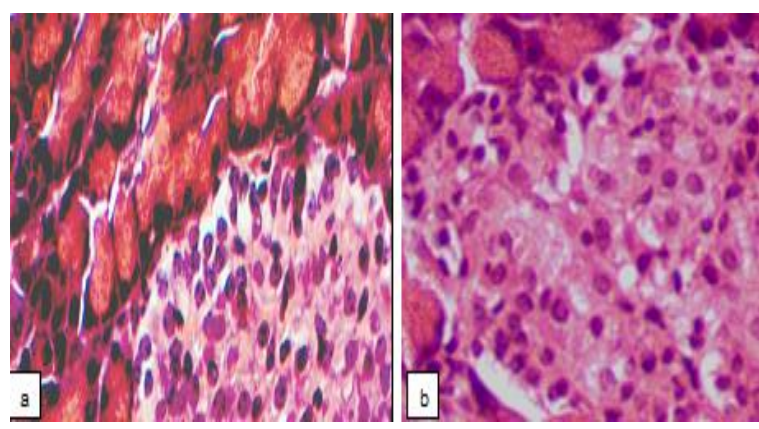

Figure1. Photomicrographs of the pancreas of the alloxan-induced diabetic rat (untreated control group)

1a. Massive destruction and cell death in the places of typical $\beta$-cells localization $(\times 400)$. Hematoxylin and eosin staining

1b. Decrease in cells number in the islet with the devastation of the central zone $(\times 400)$. Hematoxylin and eosin staining

Besides, in the in the pancreatic sections of the untreated rats the disarrangement in the islet structure was seen, with the discrepancy between the perimeter of the islets and the number of cells which were either excessively concentrated or spread over a large area. The islets with irregular shapes were found, lacking a clear border with the acinous parenchyma surrounding them. Acinar cell destruction was also present in some samples, as well as the significant reduction of the basophilic zone of the cytoplasm in these cells. In certain samples, fibrinoid swelling of the arterial interstitial vascular wall (Fig. 1c), plasmorrhagia due to increased permeability, and macrophages were seen. 
The Efficacy of Goutweed (Aegopodium Podagraria L.) Tincture and Metformin Combination in the Early Stages of Alloxan-Induced Diabetes in Rats

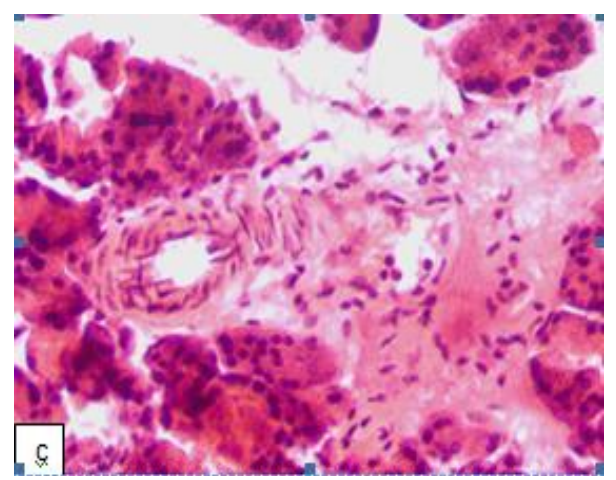

Figure1. Photomicrographs of the pancreas of the alloxan-induced diabetic rat (untreated control group)

1c. Fibrinoid swelling of the vascular wall, significant perivascular plasmorrhagia (× 250). Hematoxylin and eosin staining

Metformin effectively improved the state of the incretory apparatus of the pancreas in almost all of the animals. The number of islets in the lobes increased, although they differed in their characteristics: along with the almost normal islets (Fig. 2a), there were deserted ones (Fig. $2 b)$, as well as islets with destruction and decrease in the $\beta$-cells number or with a significant number of proliferating cells. In some cases, there was also an inconsistency between the perimeter of the islets and the number of cells.

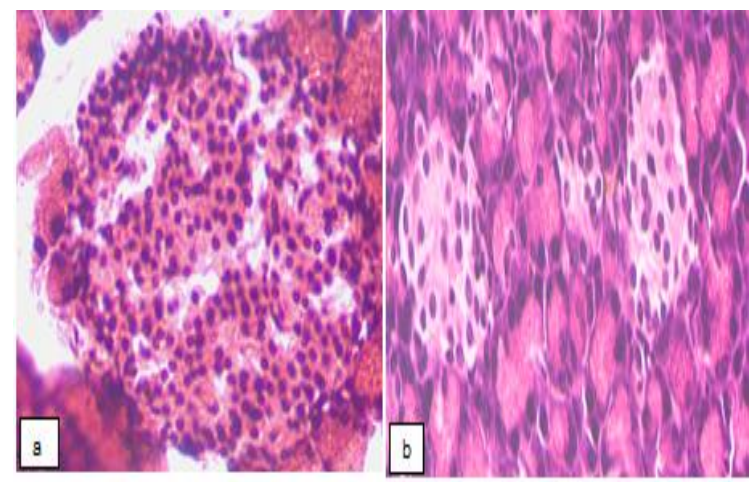

Figure2. Photomicrographs of the pancreas of the alloxan-induced diabetic rat receiving metformin

2a. Restoration of the normal number and arrangement the cells within the places of typical $\beta$ cells localization, focal proliferation in the places of typical $\alpha$-cells localization $(\times 250)$. Hematoxylin and eosin staining

2b. Devastation of the pancreatic islets $(\times 400)$. Hematoxylin and eosin staining

No pathological changes were seen in the exocrine part of the pancreatic (except for the fluctuations of the volume of basophilic and eosinophilic zones in the cytoplasm of the acinar cells); the vascular walls of the arteries were not damaged (Fig. 2c).

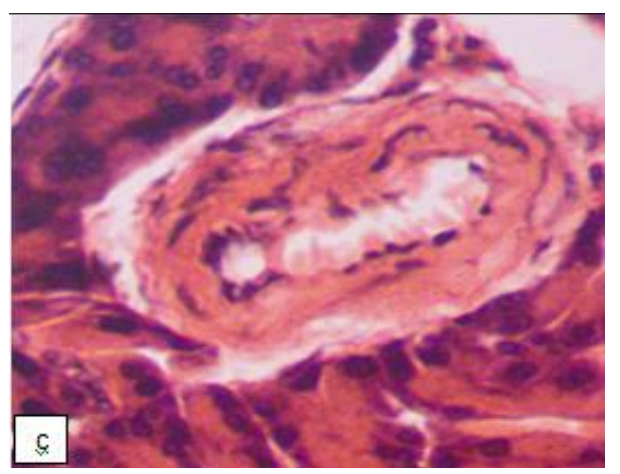

Figure2. Photomicrographs of the pancreas of the alloxan-induced diabetic rat receiving metformin

2c. The absence of the fibrinoid swelling of the vascular wall as well as perivascular plasmorrhagia ( $\times$ 400). Hematoxylin and eosin staining

Aegopodium podagraria L. tincture provided a partial protective effect on the pancreas histological structure: positive changes in the state of the incretory apparatus developed in $29 \%$ of rats, in which the number of islets in the lobes increased. The number of the cells in the islets was variable, demonstrating either decline or rise. In the part of the islets, the normal structure was restored (Fig. 3a), with a typical spatial arrangement of the cells as well as an absence of stromal edema. Along with this, the signs of apoptosis described above or destruction of the cells of different severity was registered within the core of the numerous islets. Partial devastation of the central zone was seen in certain islets. The proliferation in the places of typical $\alpha$-cells localization was limited in most of the islets (Fig. 3b).

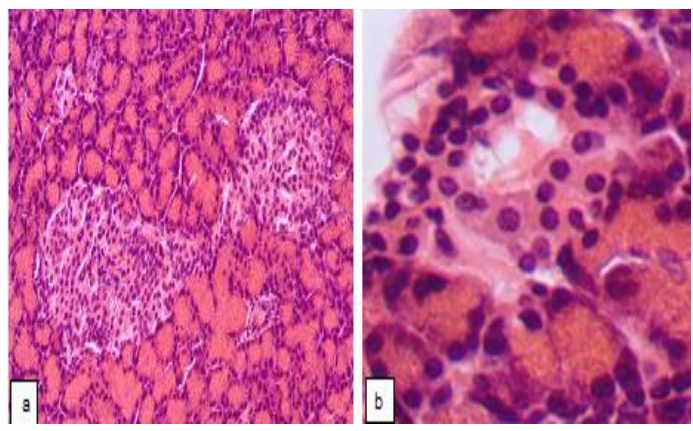

Figure3. Photomicrographs of the pancreas of the alloxan-induced diabetic rat receiving goutweed tincture

3a. Restoration of the pancreatic islets state $(\times 200)$. Hematoxylin and eosin staining

3b. Devastation of the islets, destructive changes in the places of typical $\beta$-cells localization proliferation in the places of typical $\alpha$-cells localization $(\times 400)$. Hematoxylin and eosin staining 
The perimeter of most of the islets and their cellular profiles were significantly closer to the intact control data. In the rest of the rats $(71 \%)$ no increase in the number of islets in the lobes was seen. There was a devastation of the central zone, the proliferation of the periferally located cells, the loss of a clear border between the islet and the surrounding acinus. The vascular wall of the certain intercellular arteries underwent dystrophic changes (Fig. 3c). No pathological changes were seen in the exocrine part of the pancreas (except for some fluctuations of the areas of basophilic and eosinophilic zones in the cytoplasm of the acinar cell).

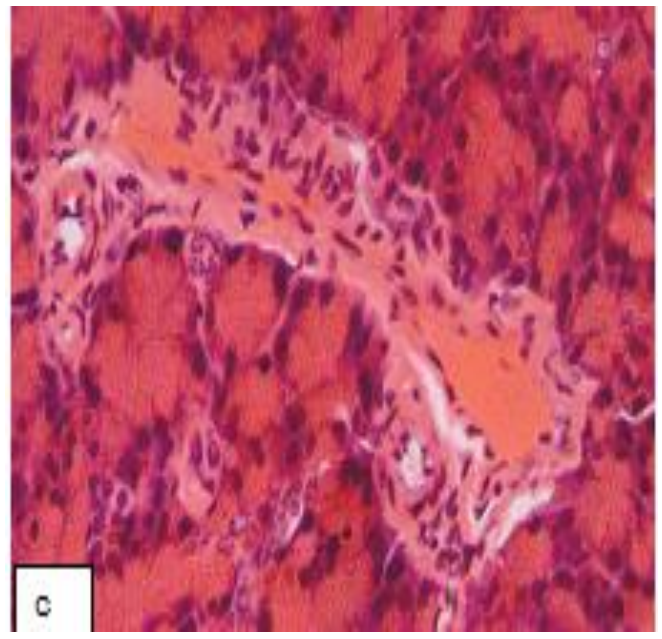

Figure3. Photomicrographs of the pancreas of the alloxan-induced diabetic rat receiving goutweed tincture

3c. Fibrinoid swelling of the vascular wall of the interlobular arteries $(\times 200)$. Hematoxylin and eosin staining

Combined administration of GW tincture and metformin appeared to be more effective than monotherapy with the tincture, although it did not significantly increase the number of pancreatic islets in the lobes (Fig. 4a). The perimeter and number of cells in the islets differed from the data of the intact control, however, the state of the cells located within the core of the islets was close to normal value and, in most of the islets, the signs of apoptosis or destructive changes were completely absent (Fig. 4b), a clear border between the islets and the surrounding acinus was maintained. In the minor part of pancreatic islets a typical arrangement of the cells as well as the border with acinus were lost, and these islets were filled with visually identical cells.

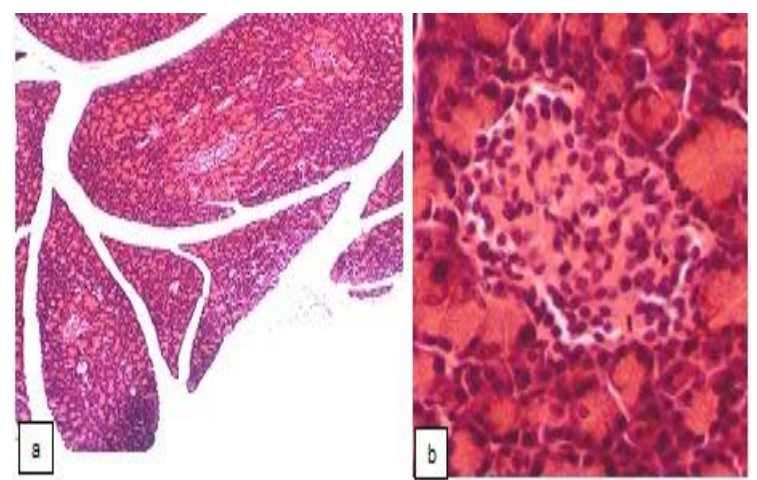

Figure4. Photomicrographs of the pancreas of the alloxan-induced diabetic rat receiving goutweed tincture combined with metformin

a. Limited increase of pancreatic islets number in the lobes $(\times 100)$. Hematoxylin and eosin staining

b. Absence of the destructive changes of $\beta$-cells $(x$ 250). Hematoxylin and eosin staining

The middle and large pancreatic islets were not registered, although there were no devastated, as well as very small islets. The proliferation of of the periferally located cells in the islets was limited, while against the background of metformin per se, these proliferating cells almost completely filled certain islets; in animals treated with the tincture per se, the proliferation of $\alpha$-cells was also significant. The structure of the exocrine part of the pancreas in all of the rats of this group was normal (with some fluctuations of the areas of basophilic and eosinophilic zones in the cytoplasm of the acinar cell). The vascular walls of the arteries were not damaged (Fig. 4c).

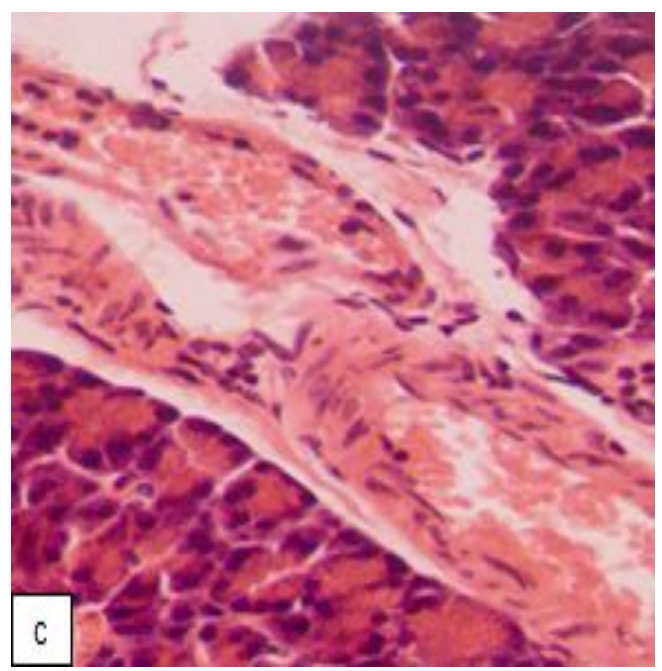

Figure4. Photomicrographs of the pancreas of the alloxan-induced diabetic rats receiving goutweed tincture combined with metformin

4c. Absence of the fibrinoid swelling of the vascular wall as well as perivascular plasmorrhagia $(\times 250)$. Hematoxylin and eosin staining 
Thus, the protective effect of metformin on the structure of the vascular wall was maintained after the combined use of this drug with GW tincture. An additional advantage of the combination studied is the limitation of proliferation within the places of typical $\alpha$-cell localization, which is not observed after monotherapy with both drugs. This mechanism is believed to be one of the pathogenetically important in alloxan-induced diabetes counteraction ${ }^{[24]}$. Furthermore, $\alpha$-cells related mechanisms leading to hyperglucagonemia are clinically relevant in patients with diabetes (including type 2diabetes) and inhibition of glucagon action is considered to be the promising antidiabetic strategy ${ }^{[29]}$. It is important to emphasize that $\alpha$-cells replication, and $\alpha$ - to $\beta$-cell conversion (which is regarded as a valuable way of increasing $\beta$-cells pool in patients with type 1 diabetes) are independent processes ${ }^{[30]}$, thus, $\alpha$-cells selective suppression is principally possible.

The liver histological structure is also altered in alloxan-induced diabetic rats. In the intact control group the normal arrangement of the hepatocytes in radiating cords, characteristic shape and size of the cells with the evenly painted and optically dense cytoplasm and normal nuclei were registered. The boundaries of the lobules were determined by triads and the narrow triads zones were seen. Epithelium of triads and other vessels was normal. Intralobular sinusoidal capillaries were moderately dilated and contained moderate number of lymphoid cells. Kupffer cells structure also was within physiological norm.

In the liver samples of the untreated group beam-lobule structure was not altered. In certain samples, fibrinoid swelling of artery wall and plasmorrhagia in whole triad zone were observed (Fig. 5a). Increase in the number of hepatocytes that underwent apoptosis was seen after alloxan administration (Fig. 5b). This is consistent with the data in the literature ${ }^{[31]}$. There also was a mild mononuclear cell infiltration of the bile ducts in some of the samples. AST and ALT activity were not elevated in all of the experimental groups (data not shown) confirming the moderate level of the liver histological changes with the absence of significant cytolisis.

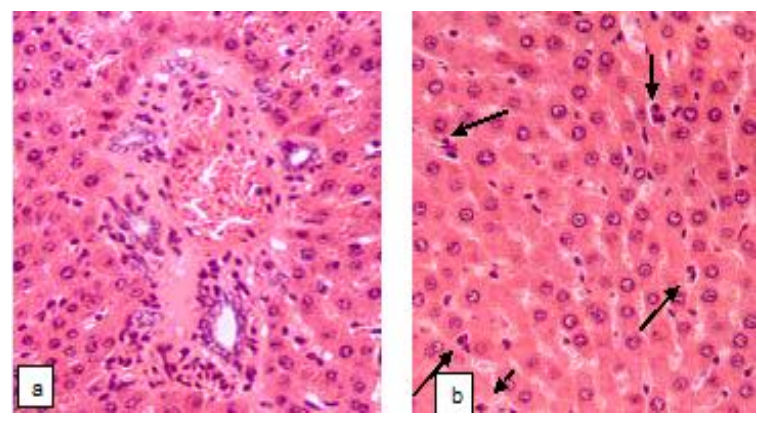

Figure5. Photomicrographs of the liver of the alloxan-induced diabetic rats. The untreated control group

5a. Fibrinoid swelling of the artery wall, plasmorrhagia in the triad zone $(\times 250)$. Hematoxylin and eosin staining

5b. Apoptotic bodies in the sinusoidal capillaries $(x$ 250). Hematoxylin and eosin staining

In the liver of diabetic rats receiving metformin, pathological changes of the hepatocytes as well as vessel walls in triads were almost completely absent (Fig. 5c). Only in one sample a very fine droplet vacuolization of hepatocytes was seen (Fig. 5d). Just in this group ALT activity showed a clear tendency towards the decrease when compared with the intact control values $(\mathrm{p}=0.06)$.
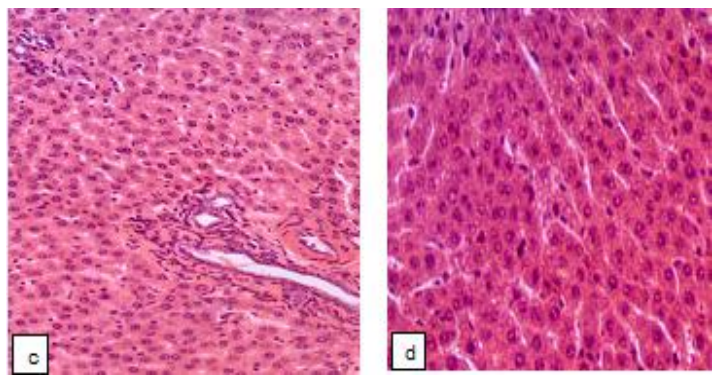

Figure5. Photomicrographs of the liver of the alloxan-induced diabetic rats. The group receiving metformin

5c. Normal structure of the vascular wall of the artery in triad (× 200). Hematoxylin and eosin staining

5d. Moderate droplet vacuolization of hepatocytes $(\times$ 250). Hematoxylin and eosin staining

GW tincture also counteracted to the apoptosis of hepatocytes (Fig. 5e). There were no alterations of beam-lobule structure, still fibrinoid swelling of artery wall of the triads was registered in the most of the samples (Fig. 5f) as well as mild mononuclear cell infiltration of the bile ducts. The previous studies showed an insufficient protective influence of the tincture at the used dose on the liver parenchyma structure of the alloxan-induced diabetic mice (this may be connected with the regimen of the tincture administration which 
The Efficacy of Goutweed (Aegopodium Podagraria L.) Tincture and Metformin Combination in the Early Stages of Alloxan-Induced Diabetes in Rats

began from day 3 when the liver injury had been already formed ${ }^{[18]}$ ).
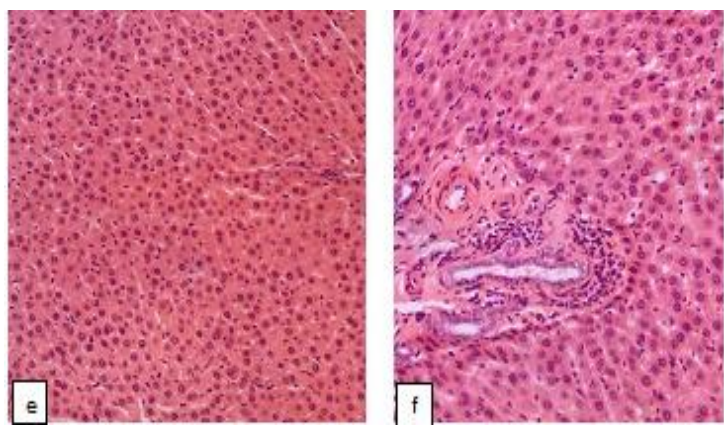

Figure5. Photomicrographs of the liver of the alloxan-induced diabetic rats. The group receiving goutweed tincture

5e. Normal structure of the liver parenchyma $(x$ 200). Hematoxylin and eosin staining

5f. Fibrinoid swelling of the artery wall, plasmorrhagia in the triad zone, moderate cellular infiltration around the bile duct $(\times 200)$. Hematoxylin and eosin staining

The expected benefits of the combined use of the tincture with metformin in regard to the liver protection were confirmed by the obtained results. The complete normalization of the liver histological structure was seen in this group. The structural organization of the liver, the state of the hepatocytes and the artery wall in the triads were within the physiological norm in all of the rats (Fig. $5 \mathrm{~g}, 5 \mathrm{~h}$ ).

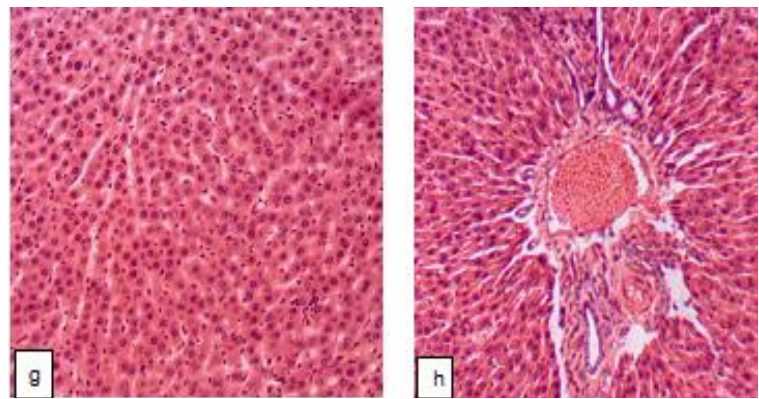

Figure5. Photomicrographs of the liver of the alloxan-induced diabetic rats. The group receiving goutweed tincture combined with metformin

5g. Normal structure of the liver parenchyma $(\times$ 200). Hematoxylin and eosin staining

5h. Normal structure of the vascular wall of the artery $(\times 200)$. Hematoxylin and eosin staining

Lethality rate did not differ between the groups of diabetic rats and was within the range of $12,5-22,2 \%$ that is expected proceeding from the early terms of the study finishing.

The results of the biochemical studies are in good agreement with the histological data. The loss of the significant quantity of $\beta$-cells and the injury of those remaining led to the fivefold decrease in plasma insulin level (Table 1).

Table1. Influence of A. podagraria tincture and metformin on the metabolic values in alloxan-induced diabeticrats; Mean \pm S.E.M; $Q_{50}\left(Q_{25}-Q_{75}\right), n=6-12$ in each group

\begin{tabular}{|c|c|c|c|c|c|}
\hline & $\begin{array}{l}\text { Intact } \\
\text { control }\end{array}$ & $\begin{array}{c}\text { Untreated } \\
\text { control (AD) }\end{array}$ & $\begin{array}{c}\mathrm{AD} \\
+ \text { metformin, } \\
100 \mathrm{mg} / \mathrm{kg}\end{array}$ & $\begin{array}{c}\mathrm{AD}+\mathrm{GW} \text { tincture } \\
1 \mathrm{ml} / \mathrm{kg}\end{array}$ & $\begin{array}{c}\mathrm{AD}+\mathrm{GW} \\
\text { tincture, } 1 \mathrm{ml} / \mathrm{kg} \\
+ \text { metformin, } \\
100 \mathrm{mg} / \mathrm{kg}\end{array}$ \\
\hline $\begin{array}{c}\text { Glycemia after } \\
\text { anaesthesia, } \\
\text { mM/l }\end{array}$ & $\begin{array}{c}6.60 \pm 0.37 \\
\mathbf{6 , 4 0} \\
(6.04-7.10)\end{array}$ & $\begin{array}{c}18.9 \pm 5.02 \\
\mathbf{1 3 . 4 ^ { * * }} \\
(7.61-21.7)\end{array}$ & $\begin{array}{c}10.3 \pm 2.74 \\
\mathbf{7 . 0 9} \\
(5.76-11.7)\end{array}$ & $\begin{array}{c}14.1 \pm 2.75 \\
9.58^{* *} \\
(8.37-20.6)\end{array}$ & $\begin{array}{c}15.4 \pm 3.34 \\
\mathbf{1 4 . 5}^{* *} \\
(8.19-21.7)\end{array}$ \\
\hline $\begin{array}{c}\text { Insulinemia, } \\
\mu \mathrm{IU} / \mathrm{ml}\end{array}$ & $\begin{array}{c}3.12 \pm 0.15 \\
\mathbf{3 . 0 0} \\
(2.95-3.15)\end{array}$ & $\begin{array}{c}0.61 \pm 0.10 \\
\mathbf{0 . 6 5}^{* * *} \\
(0.31-0.79)\end{array}$ & $\begin{array}{c}0.91 \pm 0.10 \\
\mathbf{0 . 9 0 * *} \\
(0.71-1.07)\end{array}$ & $\begin{array}{c}0.99 \pm 0.26 \\
\mathbf{0 . 7 3} \\
(0.61-1.40)\end{array}$ & $\begin{array}{c}1.18 \pm 0.19 \\
\mathbf{1 . 0 0 * \# \#} \\
(0.91-1.19)\end{array}$ \\
\hline $\begin{array}{c}\text { Insuline } \\
\text { resistance index }\end{array}$ & $\begin{array}{c}7.12 \pm 0.65 \\
\mathbf{6 . 9 6} \\
(6.30-8.21) \\
\end{array}$ & $\begin{array}{c}0.89 \pm 0.16 \\
\mathbf{1 . 0 3}^{* * *} \\
(0.42-1.31) \\
\end{array}$ & $\begin{array}{c}1.97 \pm 0.26 \\
\mathbf{1 . 7 3}^{* * \# \#} \\
(1.65-2.15) \\
\end{array}$ & $\begin{array}{c}1.53 \pm 0.43 \\
\mathbf{1 . 0 9} \\
(1.02-1.82) \\
\end{array}$ & $\begin{array}{c}1.64 \pm 0.19 \\
\mathbf{1 . 6 5}^{* * \#} \\
(1.34-1.69) \\
\end{array}$ \\
\hline $\begin{array}{c}\text { TNF- } \alpha \text { of blood } \\
\text { plasma, pg/ml }\end{array}$ & $\begin{array}{c}27.9 \pm 0.85 \\
\mathbf{2 8 . 3} \\
(27.8-28.9)\end{array}$ & $\begin{array}{c}65.1 \pm 5.84 \\
\mathbf{6 9 . 0 * *} \\
(59.8-77.7)\end{array}$ & $\begin{array}{c}50.6 \pm 7.18 \\
\mathbf{4 9 . 6}^{* *} \\
(33.0-65.7)\end{array}$ & $\begin{array}{c}64.0 \pm 8.37 \\
\mathbf{6 4 . 2} \\
(52.2-79.7)\end{array}$ & $\begin{array}{c}66.7 \pm 3.10 \\
64.2^{* *} \\
(61.7-70.7)\end{array}$ \\
\hline $\begin{array}{c}\text { Liver glycogen, } \\
\mathrm{mg} / \mathrm{g}\end{array}$ & $\begin{array}{c}1.29 \pm 0.40 \\
\mathbf{0 . 8 9} \\
(0.63-1.35)\end{array}$ & $\begin{array}{c}1.95 \pm 0.51 \\
\mathbf{1 . 2 0} \\
(0.77-2.10)\end{array}$ & $\begin{array}{c}1.91 \pm 0.40 \\
\mathbf{1 . 8 2} \\
(1.26-2.09)\end{array}$ & $\begin{array}{c}1.74 \pm 0.49 \\
\mathbf{1 . 0 3} \\
(0.71-2.77)\end{array}$ & $\begin{array}{c}1.28 \pm 0.36 \\
\mathbf{0 . 8 5} \\
(0.63-1.57)\end{array}$ \\
\hline $\begin{array}{l}\text { Total protein, } \\
\text { g/l }\end{array}$ & $\begin{array}{c}68.9 \pm 1.48 \\
\mathbf{6 9 . 5} \\
(66.5-71.0)\end{array}$ & $\begin{array}{c}62.8 \pm 2.96 \\
\mathbf{6 4 . 4} \\
(57.8-68.2)\end{array}$ & $\begin{array}{c}62.6 \pm 2.03 \\
\mathbf{6 3 . 4} \\
(60.6-64.2)\end{array}$ & $\begin{array}{c}66.7 \pm 2.65 \\
\mathbf{6 6 . 5} \\
(62.5-67.4)\end{array}$ & $\begin{array}{c}65.7 \pm 1.51 \\
\mathbf{6 5 . 2} \\
(64.0-68.5)\end{array}$ \\
\hline Albumin, $\mathrm{g} / \mathrm{l}$ & $\begin{array}{c}31.2 \pm 1.02 \\
\mathbf{3 1 . 4} \\
(29.5-33.3)\end{array}$ & $\begin{array}{c}30.0 \pm 0.85 \\
\mathbf{3 0 . 1} \\
(28.2-32.2)\end{array}$ & $\begin{array}{c}29.6 \pm 1.36 \\
\mathbf{2 8 . 8} \\
(26.9-30.9) \\
\end{array}$ & $\begin{array}{c}30.8 \pm 2.20 \\
\mathbf{3 1 . 0} \\
(29.1-34.2) \\
\end{array}$ & $\begin{array}{c}33.4 \pm 0.74 \\
\text { 32.6 }^{\#} \\
(32.3-35.2)\end{array}$ \\
\hline
\end{tabular}


The Efficacy of Goutweed (Aegopodium Podagraria L.) Tincture and Metformin Combination in the Early Stages of Alloxan-Induced Diabetes in Rats

\begin{tabular}{|c|c|c|c|c|c|}
\hline $\begin{array}{c}\text { Plasma insulin } \\
- \text { TNF- } \alpha\end{array}$ & +0.30 & +0.12 & +0.60 & $\begin{array}{c}\mathbf{- 0 . 8 9} \\
\mathbf{p}<\mathbf{0 . 0 5}\end{array}$ & $\begin{array}{c}-0.71 \\
\text { NS }\end{array}$ \\
\hline $\begin{array}{c}\text { Plasma insulin } \\
- \text { glycemia }\end{array}$ & +0.10 & -0.23 & +0.20 & -0.21 & +0.75 \\
NS & NS & NS & NS & NS \\
\hline $\begin{array}{c}\text { Liver glycogen } \\
- \text { glycemia }\end{array}$ & +0.46 & -0.51 & -0.20 & -0.61 & -0.41 \\
& NS & NS & NS & NS & NS \\
\hline
\end{tabular}

Notes: * $-p<0.05$ compared to intact control; $* *-p<0.01$ compared to intact control; $* * *-p<0.001$ compared to intact control; \# - p<0.05 compared to the untreated group; \#\# $-p<0.01$ compared to the untreated group; \&-<0.05 compared to the group receiving metformin.

$A D$ - alloxan-induced diabetes, GW-goutweed, NS-not significant.

\section{Medians are highlighted in bold.}

Together with the relative predominance of the proliferating $\alpha$-cells with the probable hyperglucagonemia this resulted in significant hyperglycemia (with the significant interindividual differences) and the abrupt decline in insulin resistance index. There was no significant correlation between plasma insulin and glycemia both in intact and in untreated animals which may be explained by the fasting state of the animals at the time of sampling. Liver glycogen tended to the increase in diabetic animals (except for those treated with the studied combination). It has long been known that in alloxan-induced diabetic rats in the fasting state (in contrast to the fed state) liver glycogen level can be higher than in the intact animals ${ }^{[32]}$. The increase of glycogen content was shown to be caused by the increased rate of synthesis (the significant activation of the liver glycogen synthase) and not a decreased rate of enzyme degradation ${ }^{[33]}$. These phenomena are also supported by later studies which emphasize the role of hyperglycemia and enhanced gluconeogenesis in the accumulation of the liver glycogen in alloxan-induced diabetic rats ${ }^{[34]}$.

The interrelation between plasma glucose and liver glycogen also did not reach the level of statistical significance but its direction changed to negative in all of the groups of the diabetic rats that may indicate that glycogenolysis role in glycemia maintaining was decreased (supposing that gluconeogenesis was also enhanced in these groups and glucose utilization by the peripheral tissues was impaired).

The protective influence of metformin, which might be expected on this model proceeding from both of the data in the literature and the histological findings discussed above, was confirmed by the significant restoration of insulin resistance index (Table 1) while glycemia and insulinemia tended to the normalization ( $\mathrm{p}=0.07$ when compared with the untreated control values in both cases). The effect of the tincture on these values was moderate and did not reach the level of statistical significance. The benefits of the investigated combination are manifested in the restoration of insulinemia (only in this group statistically significant differences with the untreated control data were registered) and insulin resistance index. Despite the previously obtained data about hypoglycemic effect of the tincture in alloxan-induced diabetic mice ${ }^{[17]}$ (and also in the other models ${ }^{[9-12]}$ ) this effect was not seen in our study after monotherapy with this preparation and its combined use with metformin (still there were no significant differences between the data of the group receiving metformin per se and the group receiving it in combination with the tincture). Basal level of glycemia was not evaluated in the study (in contrast to the results ${ }^{[17]}$ ), while in anaesthetized rats certain shifts were possible taking into account the ability of GW tincture just in this dose to counteract the effect of thiopental ${ }^{[35]}$. As discussed previously ${ }^{[13]}$, in such situation higher doses of this agent would be needed to obtain anaesthesia, increasing the effect of thiopental on glycemia which is dosedependent ${ }^{[36]}$, although, there is not enough data concerning these effects in diabetic animals as well as data about the changes of thiopental pharmacokinetics in this case.

However, it is known that thiopental does not influence on insulin signalling [37] and this allows using it in the studies of the metabolic changes. The absence of hypoglycemic action while the insulin level and insulin resistance index were significantly elevated might be interrelated with glycogenolysis changes, since the liver glycogen level tended to the decrease in animals receiving he tincture, especially in combination with metformin. 
Partially the absence of the high efficacy of GW tincture may be connected with the regimen of its administration used in the study. As GLUT2 is the common target for alloxan and glucose, increased glycemia partially prevents alloxan $\beta$ cell toxicity ${ }^{[14]}$. The preventive mode of GW tincture administration was used in our study, thus it is highly probable that alloxan injection in these animals occurred against a background of lower glycemia because just this dose exerts a hypoglycemic action after single administration [13]. This could contribute to the increased alloxan toxicity compared with all other groups which did not receive the drugs before alloxan. Such phenomena were not evident in the previous studies on mice (using the other regimen of the tincture administration) in which the high efficacy of the studied herbal preparation was registered ${ }^{[17]}$. Besides, for all of the compounds with antioxidative properties, including those of herbal origin (especially phenolic compounds, such as flavonoids) the reversion of the effect into the prooxidative one is possible ${ }^{[38]}$. Given that the free radicals processes contribute to alloxan toxicity ${ }^{[14]}$, its injection against a background of GW components might be not favourable.

Still even under these, possibly unfavourable conditions caused by the regimen of administration and selection of the terms of the study, the toxicity of the components was not increased in investigated combination, furthermore, certain positive changes were seen in these animals, such as an improvement of the histological structure of the pancreas with with the decrease in apoptosis signs and limitation of the proliferation within the places of typical $\alpha$ cells localization (partially restoring insulinemia), normalization of the liver structure with antiapoptotic effect as well as the improvement of the vessels wall structure in both organs. The improvement of the pancreas structure may form the background for the future recovery and this is indirectly supported by the tincture efficacy registered in the later stagesof alloxan-induced diabetes ${ }^{[17]}$.

The important cytokine TNF- $\alpha$ which has a pathogenetic role in $\beta$-cells apoptotic death ${ }^{[39]}$ and is recognized as a contributing factor in insulin resistance and dyslipidemia ${ }^{[40]}$ was not downregulated in all of the experimental groups (the tendency towards the reduction was seen in the group receiving metformin, Table 1). Still the negative correlation between insulinemia and TNF- $\alpha$ appeared against the background of the tincture. This may indicate the possible protective role of $\mathrm{GW}$ active components (which was limited because of the early term of the study). Plant polyphenols have been shown to protect $\beta$-cells from the damage induced by cytokines including TNF- $\alpha{ }^{[41}$ and such GW components as flavonoids demonstrate these properties in vitro ${ }^{[42]}$. The data obtained in vivo support the ability of kaempferol and ferulic acid to counteract cytokine-induced $\beta$-cells injury ${ }^{[43,44]}$. Antiapoptotic properties of hydroxicinnamic acids, which are one of the most important GW components, are also principally possible (confirmed in peripheral blood mononuclear cells ${ }^{[45]}$ ).

The protective effect of the investigated combination was also partially seen in the normalization of albumin level in plasma and the tendency toward normalization of the total protein level, while in the untreated control group and, especially under the influence of metformin, plasma total protein level decreased.

\section{Conclusion}

The expedience of the combined use of Aegopodium podagraria L. tincture with metformin which allows reducing the effective dose of the latter was established previously. This study aimed to verify the safety and efficacy of such combination under the severe conditions of the pancreas injury - during the period of maximal $\beta$-cells destruction by alloxan. According to the results, there were no signs of toxic effects of the combination investigated while the certain benefits were seen, namely the partial improvement of the pancreas histological structure with the limitation of proliferation within the places of typical $\alpha$-cells localization (not present after monotherapy) and the maintenance of the antiapoptotic effects and the protective influence on the vascular wall (inherent in the components of the combination and registered also in the liver), normalization of insulinemia, insulin resistance index, as well as plasma albumin 
level (but not glycemia that may be connected with the used terms of the study).

\section{ACKNOWLEDGMENTS}

The authors would like to acknowledge the staff of the Central Scientific-Research Laboratory of National University of Pharmacy and the researcher T.K. Yudkevich for hosting the research.

\section{REFERENCES}

[1] Martel J., Ojcius D.M., Chang C.J., Lin C.S., Lu C.C., Ko Y.F. et al. Anti-obesogenic and antidiabetic effects of plants and mushrooms, Nat. Rev. Endocrinol. 13(3), 149-160 (2017).

[2] Zhang X.L., Chen M., Zhu L.L. and Zhou Q. Therapeutic risk and benefits of concomitantly using herbal medicines and conventional medicines: from the perspectives of evidence based on randomized controlled trials and clinical risk management, Evid. Based Complement. Alternat. Med. 2017, 9296404 (2017).

[3] Rehman S.U., Choi M.S., Choe K. and Yoo H.H. Interactions between herbs and antidiabetics: an overview of the mechanisms, evidence, importance, and management, Arch. Pharm. Res. 38, 1281-1298 (2015).

[4] J.A. Duke, M.J. Bogenschutz-Godwin, P. duCellier, P.A. Duke. Handbook of Medicinal Herbs. 2nd ed. Boca Raton: CRC Press, 2002, p. 346.

[5] Koyro O.O. Role of goutweed (Aegopodium podagraria L.) biologically active substances in nephroprotective, hepatoprotective and hypouricemic activity, Extend. abstr. of candidate's thesis. National University of Pharmacy. Kharkiv. 20p. (2014). In Ukrainian.

[6] Orav A., Viitak A., Vaher M. Identification of bioactive compounds in the leaves and stems of Aegopodium podagraria by various analytical techniques, Proc. Chem. 2(1), 152-160 (2010).

[7] Ageev V.A. Pharmacognostic study of goutweed (Aegopodium podagraria L.), Extend. abstr. of candidate's thesis. Novosibirsk State Medical University. Samara. 26 p. (2013). In Russian.

[8] O.V. Tovchiga, S.Yu. Shtrygol', S.I. Stepanova. "Use of $20 \%$ tincture of bishop'sweed with $70 \%$ ethyl alcohol as means of hypoglycemic action," Ukraine patent 104448, February 10, 2014.

[9] Tovchiga O. Effects of Aegopodium podagraria preparations on the metabolic disorders induced in rats by excess fructose combined with hydrochlorothiazide: the relationship between influence on electrolyte and carbohydrate metabolism, Int. J. Biochem. Res. Rev. 4, 8098 (2014).

[10] Tovchiga O.V. Activity of goutweed (Aegopodium podagraria L.) preparations and metformin in rats with glucose intolerance, Fitoterapiya. Chasopy`s. 2, 46-51 (2017). In Ukrainian.

[11] Tovchiga O.V. The influence of goutweed (Aegopodium podagraria L.) tincture and metformin on the carbohydrate and lipid metabolism in dexamethasone-treated rats, BMC Complement Altern Med. 16, 235 (2016).

[12] Tovchiga O.V., Gorbatch T.V., Shtrygol' S.Yu., Mishchenko M.V., Stepanova S.I., Taran A.V.. The effects of goutweed (Aegopodium podagraria L.) preparations and their combinations with metformin in rats with the disorders of the lipid and carbohydrate metabolism induced by protamine sulphate, Reviews Clin. Pharm. Drug Ther. 15(2), 31-41 (2017). In Russian.

[13] Tovchiga O.V. Effects of goutweed (Aegopodium podagraria L.) preparations on glycemia in the intact rats and against the background of metformin, Vìsnik farmaciì. 2 (90), 54-62 (2017)

[14] Parviz M. Pour (Ed.) Toxicology of the endocrine pancreas. Boca Raton: Taylor \& Francis, 2006, pp. 561-561.

[15] O.V. Stefanov (Ed.) Preclinical studies of drugs. Kyiv: Avicenna, 2001, p. 400. In Ukrainian.

[16] H.G. Vogel (Ed.) Drug discovery and evaluation: pharmacological assays. 3rd ed. Berlin; Heidelberg; New York : Springer, 2008, p. 1329.

[17] Tovchiga O.V. The influence of goutweed (Aegopodium podagraria L.) preparations on the metabolic processes in alloxan-induced diabetic mice, Pharmacol. Med. Toxicol. (Farmakolohiia ta likarska toksykolohiia). 5, 73-78 (2012). In Ukrainian.

[18] Tovchiga O.V., Synytsia V.O., Shtrygol' S.Yu., Besditko N.V. Histopathological changes of the kidneys and liver in alloxan-induced diabetic mice treated with goutweed (Aegopodium podagraria L.) medicines, Klìnična farmaciâ (Clinical pharmacy). 18(2), 22-28 (2014).

[19] Balogh É., Tóth M., Bölcsházi G., Abonyi-Tóth Z.S., Kocsis E., Semjén G. Oral hypoglycaemic drugs in alloxan-induced diabetes mellitus in dogs, Acta Vet. Brn. 77, 363-371 (2008).

[20] Pathak A.K., Sinha P.K., Sharma J. A comparative study of antidiabetic effect of 
bromocriptine and metformin in alloxaninduced diabetic rats, Int. J. Pharm. Sci. Res. 4(9), 3653-3658 (2013).

[21] Chukwunonso Obi B., Chinwuba Okoye T., Okpashi V.E., Nonye Igwe C, Olisah Alumanah E. Comparative study of the antioxidant effects of metformin, glibenclamide, and repaglinide in alloxaninduced diabetic rats, J. Diabetes Res. 2016, 1635361 (2016).

[22] Atal S., Atal S., Vyas S., Phadnis P. Bioenhancing effect of piperine with metformin on lowering blood glucose level in alloxan induced diabetic mice, Pharmacognosy Res. 8(1), 56-60 (2016).

[23] Kalapko E.N., Shtrygol S.Yu., Gorbatch T.V., Laryanovskaya Yu.B., Merzlikin S.I. A comparative analysis of $\mathrm{N}, \mathrm{N}^{\prime}$-(ethane-1,2dyyil)bis(quinoline-2-carboxamide), diakamph hydrochloride, and metformin efficacy in the acute period of alloxaninduced diabetes in rats, Vìsnik farmaciï (Vitebsk). 3(73), 2, 67-76 (2016). In Russian.

[24] Aleeva G.N. Cellular mechanisms of the development of hyperglycemia and its pharmacological correction in alloxan diabetes (experimental study), Extend. abstr. of candidate's thesis. Kazan State Medical University. Kazan. 17 p. (2003). In Russian.

[25] Lee P.N, Lovel D. Statistics for toxicology. In: Ballantyne B., Marrs T.C., Syversen T. (Eds.). General and applied toxicology. London: John Wiley \& Sons, 2009, pp. 675-669.

[26] Steiner D.J., Kim A., Miller K., Hara M. Pancreatic islet plasticity: Interspecies comparison of islet architecture and composition, Islets. 2(3), 135-145 (2010).

[27] Lasheen N.N. Pancreatic functions in high salt fed female rats. Physiol. Rep. 3(7), e12443 (2015).

[28] Mikhailichenko V.U., Stoliarov S.S. Role of insular and contra-insular hormones in the pathogenesis of alloxan diabetes in rats in the experiment, Modern problems of science and education. 4, (2015).

[29] Gromada J., Franklin I., Wollheim C.B. Alphacells of the endocrine pancreas: 35 years of research but the enigma remains, Endocr, Rev. 28(1), 84-116 (2007).

[30] Chung C.-H., Levine F. Adult pancreatic alphacells: a new source of cells for beta-cell regeneration. the review of diabetic studies, RDS. 7(2), 124-131 (2010).

[31] Bhattacharya S., Gachhui R., Sil P.C. The prophylactic role of D-saccharic acid-1,4lactone against hyperglycemia-induced hepatic apoptosis via inhibition of both extrinsic and intrinsic pathways in diabetic rats, Food Funct. 4(2), 283-296 (2013).

[32] Friedmann B., Goodman Eh. Jr., Weinhouse S. Liver glycogen synthesis in intact alloxan diabetic rats, J. Biol. Chem. 238, 2899-2905 (1963).

[33] Bahnak B.R., Gold A.H. Effects of alloxan diabetes on the turnover of rat liver glycogen synthase. Comparison with liver phosphorylase, J. Biol. Chem. 257(15), 8775-8780 (1982).

[34] Kinkar Shobha Bhanudas, Patil Kishor Gopal. Estimation of liver glycogen in normal control, diabetic control and Tinospora cordifolia extract treated albino rats, Glob. J. Sci. Front. Res. C Biol. Sci. 16(2), (2016).

[35] Tovchiga O.V. Interaction of Aegopodium podagraria L. (goutweed) with central nervous system depressants, Ukrainskyi biofarmatsevtychnyi zhurnal (Ukr. Biopharm J.) 1 (42), 31-36, (2016).

[36] Fodor J., Grafnetter D. The influence of thiopentone anaesthesia on the blood lipid and blood sugar level, Br. J. Pharmacol. Chemother. 15, 282-284 (1960).

[37] Cardoso A.R., Carvalho C.R., Velloso L.A., Brenelli S.L., Saad M.J., Carvalheira J.B. Effect of thiopental, pentobarbital and diethyl ether on early steps of insulin action in liver and muscle of the intact rat, Life Sci. 76(20), 2287-2297 (2005).

[38] Procházková D., Boušová I., Wilhelmová N. Antioxidant and prooxidant properties of flavonoids, Fitoterapia. 82(4), 513-523 (2011).

[39] Parkash J., Chaudhry M.A., Rhoten W.B. Tumor necrosis factor-alpha-induced changes in insulin-producing beta-cells, Anat. Rec. A. Discov. Mol. Cell. Evol. Biol. 286(2), 982-993 (2005).

[40] Moller D.E. Potential role of TNF-alpha in the pathogenesis of insulin resistance and type 2 diabetes, Trends Endocrinol. Metab. 11(6), 212-227 (2000).

[41] Cumaoğlu A., Ari N., Kartal M., Karasu Ç. Polyphenolic extracts from Olea europea L. protect against cytokine-induced $\beta$-cell damage through maintenance of redox homeostasis, Rejuvenation Res. 14(3), 325-334 (2011).

[42] Lin C.Y., Ni C.C., Yin M.C., Lii C.K. Flavonoids protect pancreatic beta-cells from cytokines mediated apoptosisthrough the activation of PI3-kinase pathway, Cytokine. 59(1), 65-71 (2012).

[43] Zhang Y., Liu D. Flavonol kaempferol improves chronic hyperglycemia-impaired 
The Efficacy of Goutweed (Aegopodium Podagraria L.) Tincture and Metformin Combination in the Early Stages of Alloxan-Induced Diabetes in Rats

pancreatic beta-cell viability and insulin secretory function, Eur. J. Pharmacol. 670(1), 325-322 (2011).

[44] Sompong W., Cheng H., Adisakwattana S. Ferulic acid prevents methylglyoxal-induced protein glycation, DNA damage, and apoptosis in pancreatic $\beta$-cells, J. Physiol. Biochem. 73(1), 121-131 (2017).
[45] Khanduja K.L., Avti P.K., Kumar S., Mittal N., Sohi K.K., Pathak C.M. Anti-apoptotic activity of caffeic acid, ellagic acid and ferulic acid in normal human peripheral blood mononuclear cells: a Bcl-2 independent mechanism, Biochim. Biophys. Acta. 1760(2), 283-289 (2006).

Citation: O.V. Tovchiga, S.Yu. Shtrygol, Yu. B. Laryanovskaya. The Efficacy of Goutweed (Aegopodium Podagraria L.) Tincture and Metformin Combination in the Early Stages of Alloxan-Induced Diabetes in Rats. ARC Journal of Diabetes and Endocrinology. 2017; 3(1):6-18. doi:dx.doi.org/10.20431/2455-5983.0301002.

Copyright: (C) 2017 Authors. This is an open-access article distributed under the terms of the Creative Commons Attribution License, which permits unrestricted use, distribution, and reproduction in any medium, provided the original author and source are credited. 